\title{
Progressive worsening of the respiratory and gut microbiome in children during
}

\section{the first two months of COVID-19}

\section{Running title: COVID-19 disturbs children's microbiome}

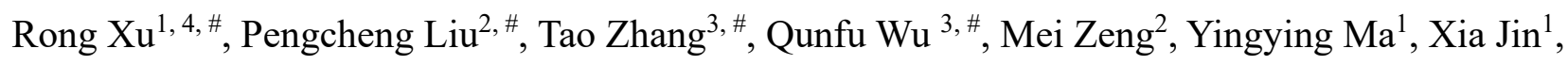
Jin $\mathrm{Xu}^{2} *$, Zhigang Zhang ${ }^{3}$, Chiyu Zhang ${ }^{1,4} *$

1. Shanghai Public Health Clinical Center, Fudan University, Shanghai 201508, China

2. Children's Hospital of Fudan University, Shanghai 201102, China

3. State Key Laboratory for Conservation and Utilization of Bio-Resources in Yunnan, School of Life Sciences, Yunnan University, Kunming, Yunnan 650091, China

4. Pathogen Discovery and Evolution Unit, Institut Pasteur of Shanghai, Chinese Academy of Sciences, Shanghai 200031, China.

\# These authors contributed equally to this work.

* Correspondence: Chiyu Zhang, Shanghai Public Health Clinical Center, Fudan University, Shanghai 201508, China. Email zhangcy1999@hotmail.com

Or Zhigang Zhang, State Key Laboratory for Conservation and Utilization of Bio-Resources in Yunnan, School of Life Sciences, Yunnan University, No. 2 North Cuihu Road, Kunming, Yunnan 650091, China. Email: zhangzhigang@ynu.edu.cn.

Or Jin Xu, Department of Clinical Laboratory, Children's Hospital of Fudan University, Shanghai 201102, China. Email: janexu@fudan.edu.cn 
medRxiv preprint doi: https://doi.org/10.1101/2020.07.13.20152181; this version posted July 17,2020 . The copyright holder for this preprint (which was not certified by peer review) is the author/funder, who has granted medRxiv a license to display the preprint in perpetuity. It is made available under a CC-BY-NC-ND 4.0 International license.

\section{Abstract}

Children are less susceptible to COVID-19 and manifests lower morbidity and mortality after infection, for which a multitude of mechanisms may be proposed. Whether the normal development of gut-airway microbiome is affected by COVID-19 has not been evaluated. We demonstrate that COVID-19 alters the respiratory and gut microbiome of children. Alteration of the microbiome was divergent between the respiratory tract and gut, albeit the dysbiosis was dominated by genus Pseudomonas and sustained for up to 25-58 days in different individuals. The respiratory microbiome distortion persisted in 7/8 children for at least 19-24 days after discharge from the hospital. The gut microbiota showed early dysbiosis towards later restoration in some children, but not others. Disturbed development of both gut and respiratory microbiomes, and prolonged respiratory dysbiosis in children imply possible long-term complications after clinical recovery from COVID-19, such as predisposition to an increased health risk in the post-COVID-19 era.

Key words: SARS-CoV-2/COVID-19; respiratory microbiota; gut microbiota, dysbiosis; children. 
medRxiv preprint doi: https://doi.org/10.1101/2020.07.13.20152181; this version posted July 17,2020 . The copyright holder for this preprint (which was not certified by peer review) is the author/funder, who has granted medRxiv a license to display the preprint in perpetuity. It is made available under a CC-BY-NC-ND 4.0 International license .

\section{Introduction}

COVID-19 caused by SARS-CoV-2 has impacted millions of peoples in more than 200 countries around the world ${ }^{1,2}$. Compared with adults, children appear to be less susceptible to COVID-19 with extremely low morbidity and mortality ${ }^{3-5}$; and children with COVID-19 often have mild symptoms with a faster recovery, and better prognosis. The reasons for these are not entirely clear. Early-life development and maturation of human microbiomes shape health status in later life ${ }^{6-9}$, and delayed development or dysbiosis of the microbiomes during childhood has been linked to predisposition to various diseases in adulthood ${ }^{7-12}$. The effect of COVID-19 on the gut microbiome had just began to be evaluated in adults ${ }^{13,14}$, but never in children. We recently evaluated the longitudinal effects of COVID-19 on both the respiratory and gut microbiome in adults, and revealed that the respiratory and gut microbiome presented a contemporaneous change from early dysbiosis towards late incomplete restoration during the course of disease ( $\mathrm{Xu}$ et al., unpublished observation). How COVID-19 impacts on the respiratory and gut microbiomes of children is not known. Here, we report temporal dynamics of respiratory and gut microbiome in children with COVID-19. 
medRxiv preprint doi: https://doi.org/10.1101/2020.07.13.20152181; this version posted July 17, 2020. The copyright holder for this preprint (which was not certified by peer review) is the author/funder, who has granted medRxiv a license to display the preprint in perpetuity. It is made available under a CC-BY-NC-ND 4.0 International license.

\section{Results}

\section{Study cohort}

Nine COVID-19 children between 7-139 months old were enrolled in this study together with 14 age-matched healthy control children. A total of 103 specimens including 27 sets of paired specimens (at least two of throat swab, nasal swab and feces) were collected from children with COVID-19 (Supplementary Fig. 1). The children were being followed between 25-58 days after symptom onset. All samples were subjected to high-throughput sequencing of the V4-region of bacterial 16S rRNA gene (Methods).

\section{Respiratory and gut microbiome dynamics in COVID-19}

We analyzed the 16S-rRNA gene sequences of all specimens from three body sites, and obtained 2,187 sub-OTUs (sOTUs) that represent 15 known phyla including 200 known genera (Supplementary Table 1). Using the DMM method (Supplementary method), we identified 8 community types (Fig.1a). The specimens from healthy children clustered into two community types, one bears the signature of stool samples (H-GUT), and another represents the collection of all three kinds of samples (throat swab, nasal swab and feces) (H-MIX). H-GUT is significantly separated from H-MIX (Fig. 1b), with significantly lower richness and evenness (Fig.1c). H-GUT was featured by Moraxella, a commensal in nasal passages of infants, implying that it might not represent a normal gut microbiome status. Because the development of infant microbiome is influenced by maternal materials from multiple sites (stool, vaginal, oral and skin) among which bacteria from maternal gut being the most important contributor ${ }^{15}$, infants and children may share the same or very similar microbial community structures of the nasal cavity, throat and gut ${ }^{16,17}$. Therefore, H-MIX represents 
medRxiv preprint doi: https://doi.org/10.1101/2020.07.13.20152181; this version posted July 17, 2020. The copyright holder for this preprint (which was not certified by peer review) is the author/funder, who has granted medRxiv a license to display the preprint in perpetuity.

It is made available under a CC-BY-NC-ND 4.0 International license .

the gut and respiratory tract microbiomes of healthy children. In fact, the nasal cavity, throat and gut still maintain similar microbial structures in adulthood.

Bacteria from stool specimens of COVID-19 children fell into three distinct community types (COVID-GUT I-III), and those from nasal and throat swabs formed another three distinct types (COVID-TN I-III) (Fig. 1a). All COVID-19-related types are significantly separated from the type H-MIX except COVID-TN-I that overlaps with H-MIX (Fig. 1b). In particular, three respiratory tractrelated types and three GUT-related types of COVID-19 children are also significantly separated from each other, and distinctly different from healthy children. These results indicated that SARS-CoV-2 infection significantly changed the gut and respiratory tract microbiota of children, and the separation of bacterial community structures between the gut and respiratory tracts suggested that the normal development of the microbiota may be impaired.

All COVID-19-related types showed lower richness and evenness than H-MIX, except for COVID-GUT-I that has the most similarity to H-MIX and relatively normal microbiome structure. There was a gradual decrease from community type I to III for both gut and respiratory tract (Fig. 1c), indicating a progressive deterioration (dysbiosis) of the microbiome. Overall, the dysbiosis appeared to be more severe in the respiratory tract than in the gut.

\section{Indicator genera of eight DMM clusters}

To characterize eight microbial community types, we identified 35 indicator genera (Fig. 2a). The H-MIX type was characterized by 11 genera, and the predominant commensal bacteria contained Prevotella, Streptococcus, unclassified Pasteurellaceae, and Actinomyces (Fig. 2b). Some of the indicator bacteria in H-MIX were shared by the community types COVID-GUT-I (e.g. Prevotella, 
medRxiv preprint doi: https://doi.org/10.1101/2020.07.13.20152181; this version posted July 17, 2020. The copyright holder for this preprint (which was not certified by peer review) is the author/funder, who has granted medRxiv a license to display the preprint in perpetuity. It is made available under a CC-BY-NC-ND 4.0 International license.

Porphyromonas, Finegoldia, Anaerococcus, etc.) and COVID-TN-I (e.g. Prevotella, Neisseria, Fusobacterium, unclassified Pasteurellaceae, Leptotrichia etc.). As a dysbiosis status, community type COVID-GUT-III was dominated by Bacteroides, as well as Parasutterella that is associated with irritable bowel syndrome and other intestinal chronic inflammation ${ }^{18}$. Community type COVID-TNIII was dominated by highly abundant Pseudomonas and Herbaspirillum, and it had higher levels of genera of Corynebacterium, Comamonadaceae, Burkholderia, Achromobacter, Brevundimonas, Ralstonia, Phyllobacterium, and Burkholderiales than other community types (Fig. 2b). Genus Pseudomonas is a notorious human pathogen associated with various diseases (e.g. pneumonia), and the samples were overwhelmed by the dominant species Pseudomonas veronii $(100 \%$ sequence identity) ${ }^{19}$. Apart from COVID-TN-III, genus Pseudomonas also dominated community type COVID-TN-II with Streptococcus, and COVID-GUT-II with Bacteroides. Furthermore, Achromobacter and Burkholderia are associated with cystic fibrosis ${ }^{20,21}$, and most other genera are environmental bacteria. The predominance of Pseudomonas together with the colonization of various environmental bacteria in type COVID-TN-III imply an extreme dysbiosis in upper respiratory tract.

\section{The dynamic change of children during COVID-19}

Recently, we observed synchronous restoration of the microbiomes of both respiratory tract and the gut towards normal structure in COVID-19 adults within a short time (6-17 days) after symptom onset ( $\mathrm{Xu}$ et al., unpublished observation). Distinct from adults, the microbiome community compositions were extremely dynamic in children during COVID-19, and the changes of the community types in the respiratory tract and gut were divergent (Fig. 3a). The respiratory (especially nasopharyngeal) microbiome of 7/8 children (except CV05) appeared to evolve from early healthy 
medRxiv preprint doi: https://doi.org/10.1101/2020.07.13.20152181; this version posted July 17, 2020. The copyright holder for this preprint (which was not certified by peer review) is the author/funder, who has granted medRxiv a license to display the preprint in perpetuity.

It is made available under a CC-BY-NC-ND 4.0 International license .

(H-MIX) or high-diversity community structures (COVID-TN-I) to late low-diversity dysbiosis structure (COVID-TN-III), indicating a steady deterioration in composition and function of the respiratory microbiome despite a fast clinical recovery (Fig. 3a). Surprisingly, the respiratory dysbiosis was sustained at least 19-24 days after discharge (i.e., $42-58$ days after symptom onset) in three children (CV01, CV02 and CV09).

In contrast, the gut microbiome alternation varied greatly among these COVID-19 children. Improvement or restoration was observed in three children (CV01, CV02 and CV05), but a worsening trend of unstable bacterial genera occurred in another three children (CV03, CV04 and CV09) (Fig. 3a). For example, the community type of CV09 improved from COVID-GUT-II to COVID-GUT-I on day 7 after symptom onset, but deteriorated to COVID-GUT-III on day 37. For CV03, whose microbiome got worse from a gut community type COVID-GUT-II on day 19 to a respiratory community type COVID-TN-III on day 27 , and returned to COVID-GUT-II on day 43 . The shift from a slightly dysbiosis gut community type to a severely dysbiosis respiratory community type implies microbial translocations from respiratory tract to gut. The restoration or worsening of the gut microbiome showed no association with clinical recovery (discharge from the hospital) or the presence or absence of SARS-CoV-2 RNA in the gut (Fig.3a).

Our data clearly demonstrate a progressively worsening of microbiome in both the respiratory tract and gut of children during the course of COVID-19. The worsening was predominantly driven by Pseudomonas species P.veronii (Fig. 3b and Supplementary Fig. 2), which was the most prevalent Pseudomonas species identified, and had a relative abundance of over 20\% in most COVID-19 children. Genus Streptococcus (mainly S.mitis) also contributed to the worsening of the microbiome ${ }^{22}$. On the other hand, the presence of probiotic Bifidobacterium and the most important butyrate- 
medRxiv preprint doi: https://doi.org/10.1101/2020.07.13.20152181; this version posted July 17,2020 . The copyright holder for this preprint (which was not certified by peer review) is the author/funder, who has granted medRxiv a license to display the preprint in perpetuity.

It is made available under a CC-BY-NC-ND 4.0 International license.

producing bacteria Faecalibacterium were inversely correlated with the existence of Pseudomonas

(Fig. 3b and Supplementary Fig. 2), despite these beneficial bacteria presented at a very low relative abundance and often decreased in late disease stage.

\section{Bacteria-bacteria co-occurrence networks}

The co-occurrence network analysis revealed significant microbial cross-talk among different

body sites of children with COVID-19 (Fig. 4). There were three main co-occurrence networks

identified. Positive co-occurrence relationships were observed within and between bacteria from the respiratory tract and the gut (FDR-adjusted $\mathrm{P}<0.001$, Pearson correlation $\mathrm{r}>0.4$ ), indicating the presence of frequent bacterial cross-talk between different body sites. Similar to our observation in adults, the co-occurrence networks were relatively separated by different diversity-levels of community types, but not by body sites. For example, bacteria from the community type COVIDTN-III are closely associated with those from COVID-TN-II and COVID-GUT-II (Fig. 4). In this network, Pseudomonas was positively correlated with some environmental bacteria. In another two networks, probiotic (e.g. Bifidobacterium and Faecalibacterium) were mainly correlated with commensals and community types H-MIX, COVID-GUT-I, COVID-TN-I and COVID-TN-II (Fig. 
medRxiv preprint doi: https://doi.org/10.1101/2020.07.13.20152181; this version posted July 17, 2020. The copyright holder for this preprint (which was not certified by peer review) is the author/funder, who has granted medRxiv a license to display the preprint in perpetuity.

It is made available under a CC-BY-NC-ND 4.0 International license .

\section{Discussion}

SARS-CoV-2 infection causes damage to multiple organs either through direct infection, or indirectly disrupt host homeostasis, including perturbation of gut and respiratory microbiota in adults.

Here, we report the first longitudinal investigation of microbiome with sampling from multiple anatomical sites of children with COVID-19, and present evidence that children have distinct differences compared to adults ( $\mathrm{Xu}$, unpublished observations), with respect to the dynamic changes of microbiota during the course of disease. The study of children is a significant feature because earlylife microbiome plays important roles in the development of host immunity, metabolism, and neural systems, affecting profoundly health status in later life ${ }^{7}$. The microbiome attains a relatively stable adult-like structure at the age 3 after a highly dynamic initial developmental (months 3-14) phase, a transitional (months 15-30) phase, and finally a stable phase (months $31-46)^{16}$. The development of infants' microbiomes is more easily influenced by various internal (genetic) and external factors (e.g. birth mode, feeding type, siblings, antibiotics, and infection) $)^{7,9}$, and maternal gut strains provide the largest contribution to the microbiome composition ${ }^{15}$. Early-life microbiome disruption caused by antibiotics and malnutrition is associated with increased risk of health problems later in childhood and even adulthood, such as developmental retardation, allergic diseases, obesity, diabetes and immune dysfunction $3-5,23,24$.

SARS-CoV-2 infection impaired the respiratory and gut microbiota in both adults and children, but the respiratory and gut microbiome of children and adults faced diverging fates (Supplementary Fig. 3). In some mild adult cases, the respiratory and gut microbiomes showed a synchronous restoration from early dysbiosis towards later near-normal structure within a short period (6-17 days), substantially earlier than their clinical recovery (Xu et al. unpublished observation). In children, 
medRxiv preprint doi: https://doi.org/10.1101/2020.07.13.20152181; this version posted July 17, 2020. The copyright holder for this preprint (which was not certified by peer review) is the author/funder, who has granted medRxiv a license to display the preprint in perpetuity.

It is made available under a CC-BY-NC-ND 4.0 International license.

however, the dynamic changes of the microbiome were divergent between respiratory tract and gut, and the microbiome appeared to be progressively worsening, especially in the respiratory tract for a long period (25-52 days), substantially later than their clinical recovery (12-37 days) (Supplementary Fig. 3). In this cohort, six children were older than 3 years of age, and should have relatively stable adult-like microbiome. The dynamic characteristics of the microbiome during COVID-19 implied that children's microbiome is still particularly vulnerable and less resilient than that of the adults even after attaining a stable phase $e^{7,9,16}$. Importantly, the persistent worsening of the microbiomes caused by COVID-19 might impart potential short-term and long-term health problems during childhood and adulthood.

We and other have reported that altered respiratory microbiome with reduced bacterial diversity increased the susceptibility of children to acute respiratory tract infections (ARTIs) ${ }^{6,8,25-27}$. The impaired microbiome in children with COVID-19 is characterized by Pseudomonas-dominated community types that favor the colonization and growth of pathogenic and environmental bacteria, and a reduction of some beneficial commensals (Fig. 4). Probiotic (e.g. Bifidobacterium) and butyrate-producing bacteria (e.g. Faecalibacterium) that have anti-inflammatory ability were extensively depleted from the gut and respiratory microbiomes of the children especially at late stage of COVID-19 (Fig. 3b) (2,29 $^{2}$ Low abundance or lack of butyrate-producing bacteria might tolerate low-level inflammation induced by SARS-CoV-2, rendering children more vulnerable to ARTIs and diarrheal diseases ${ }^{8,9,30}$. In particular, the enrichment of genera Moraxella and Streptococcus in these COVID-19 children might predispose them to an increased risk of recurrent ARTIs ${ }^{6}$.

To the best of our knowledge, this is the first report on the complex dynamics of the gut and respiratory microbiota in children with COVID-19. Disturbed development of both gut and 
medRxiv preprint doi: https://doi.org/10.1101/2020.07.13.20152181; this version posted July 17, 2020. The copyright holder for this preprint (which was not certified by peer review) is the author/funder, who has granted medRxiv a license to display the preprint in perpetuity. It is made available under a CC-BY-NC-ND 4.0 International license .

respiratory microbiomes, and prolonged respiratory dysbiosis caused by SARS-CoV-2 infection imply possible short-term and long-term complications after they have recovered from COVID-19, and predispose afflicted children to an increased health risk in later life. Although the long-term outcomes of COVID-19 on children need to be further studied with more extended follow-up and larger cohort, our data suggest that early implementation of various intervention strategies to modulate the microbiome development may provide clinical benefit to children in the post COVID19 era.

\section{Online content}

Any methods, additional references, source data, extended data, supplementary information, acknowledgements, details of author contributions and competing interests, and statements of data and number availability are available.

\section{1}

Zhu, N. et al. A Novel Coronavirus from Patients with Pneumonia in China, 2019. New Eng/ J Med 382, 727-733 (2020).

2 Zhou, P. et al. A pneumonia outbreak associated with a new coronavirus of probable bat origin. Nature 579, 270-273 (2020).

3 Guan, W. et al. Clinical Characteristics of Coronavirus Disease 2019 in China. New Engl J Med 382, 1708$1720(2020)$.

4 Wu, Z. Y. \& McGoogan, J. M. Characteristics of and Important Lessons From the Coronavirus Disease 2019 (COVID-19) Outbreak in China Summary of a Report of 72314 Cases From the Chinese Center for Disease Control and Prevention. Jama-J Am Med Assoc 323, 1239-1242 (2020).

5 Onder, G., Rezza, G. \& Brusaferro, S. Case-Fatality Rate and Characteristics of Patients Dying in Relation to COVID-19 in Italy. Jama-J Am Med Assoc 323, 1775-1776 (2020).

6 Teo, S. M. et al. The Infant Nasopharyngeal Microbiome Impacts Severity of Lower Respiratory Infection and Risk of Asthma Development. Cell Host Microbe 17, 704-715 (2015).

7 Derrien, M., Alvarez, A. S. \& de Vos, W. M. The Gut Microbiota in the First Decade of Life. Trends Microbiol 27, 997-1010 (2019).

8 Dubourg, G., Edouard, S. \& Raoult, D. Relationship between nasopharyngeal microbiota and patient's susceptibility to viral infection. Expert Rev Anti-Infe 17, 437-447 (2019).

9 Man, W. H., Piters, W. A. A. D. \& Bogaert, D. The microbiota of the respiratory tract: gatekeeper to respiratory health. Nat Rev Microbio/ 15, 259-270 (2017). 
medRxiv preprint doi: https://doi.org/10.1101/2020.07.13.20152181; this version posted July 17, 2020. The copyright holder for this preprint (which was not certified by peer review) is the author/funder, who has granted medRxiv a license to display the preprint in perpetuity. It is made available under a CC-BY-NC-ND 4.0 International license .

Blanton, L. V. et al. Gut bacteria that prevent growth impairments transmitted by microbiota from malnourished children. Science 351, 10.1126/science.aad3311 aad3311 (2016).

11 Gehrig, J. L. et al. Effects of microbiota-directed foods in gnotobiotic animals and undernourished children. Science 365, eaau4732 (2019).

12 Cox, L. M. et al. Altering the Intestinal Microbiota during a Critical Developmental Window Has Lasting Metabolic Consequences. Ce// 158, 705-721 (2014).

$3 \mathrm{Gu}, \mathrm{S}$. et al. Alterations of the Gut Microbiota in Patients with COVID-19 or H1N1 Influenza. Clin Infect Dis, ciaa709 (2020).

14 Zuo, T. et al. Alterations in Gut Microbiota of Patients With COVID-19 During Time of Hospitalization. Gastroenterology, ciaa709 (2020).

15 Ferretti, P. et al. Mother-to-Infant Microbial Transmission from Different Body Sites Shapes the Developing Infant Gut Microbiome. Cell Host Microbe 24, 133-145.e135 (2018).

16 Stewart, C. J. et al. Temporal development of the gut microbiome in early childhood from the TEDDY study. Nature 562, 583-588 (2018).

17 Ding, T. \& Schloss, P. D. Dynamics and associations of microbial community types across the human body. Nature 509, 357-360 (2014).

18 Chen, Y. J. et al. Parasutterella, in association with irritable bowel syndrome and intestinal chronic inflammation. J Gastroen Hepato/33, 1844-1852 (2018).

19 Cheuk, W., Woo, P. C. Y., Yuen, K. Y., Yu, P. H. \& Chan, J. K. C. Intestinal inflammatory pseudotumour with regional lymph node involvement: identification of a new bacterium as the aetiological agent. $J$ Pathol 192, 289-292 (2000).

20 Spilker, T., Vandamme, P. \& LiPuma, J. J. Identification and distribution of Achromobacter species in cystic fibrosis. J Cyst Fibros 12, 298-301 (2013).

21 Jones, A. M. et al. Burkholderia cenocepacia and Burkholderia multivorans: influence on survival in cystic fibrosis. Thorax 59, 948-951 (2004).

22 Mitchell, J. Streptococcus mitis: walking the line between commensalism and pathogenesis. Mol Oral Microbio/ 26, 89-98 (2011).

23 Livanos, A. E. et al. Antibiotic-mediated gut microbiome perturbation accelerates development of type 1 diabetes in mice. Nat Microbio/ 1, 16140 (2016).

24 Grier, A. et al. Neonatal gut and respiratory microbiota: coordinated development through time and space. Microbiome 6, 193 (2018).

Man, W. H. et al. Bacterial and viral respiratory tract microbiota and host characteristics in children with lower respiratory tract infections: a matched case-control study. Lancet Resp Med 7, 417-426 (2019). Langevin, S. et al. Early nasopharyngeal microbial signature assod
a retrospective pilot study. J. Gen. Virol. 98, 2425-2437 (2017).

Piters, W. A. A. D. et al. Nasopharyngeal Microbiota, Host Transcriptome, and Disease Severity in Children with Respiratory Syncytial Virus Infection. Am J Resp Crit Care 194, 1104-1115 (2016).

28 Riviere, A., Selak, M., Lantin, D., Leroy, F. \& De Vuyst, L. Bifidobacteria and Butyrate-Producing Colon Bacteria: Importance and Strategies for Their Stimulation in the Human Gut. Frontiers in Microbiology 7 , 979 (2016).

29 Lopez-Siles, M., Duncan, S. H., Garcia-Gil, L. J. \& Martinez-Medina, M. Faecalibacterium prausnitzii: from microbiology to diagnostics and prognostics. Isme J11, 841-852 (2017).

$30 \mathrm{Li}$, Y. P. et al. Altered respiratory virome and serum cytokine profile associated with recurrent respiratory tract infections in children. Nat Commun 10, 2288 (2019). 
medRxiv preprint doi: https://doi.org/10.1101/2020.07.13.20152181; this version posted July 17, 2020. The copyright holder for this preprint (which was not certified by peer review) is the author/funder, who has granted medRxiv a license to display the preprint in perpetuity.

It is made available under a CC-BY-NC-ND 4.0 International license.

\section{Figure legends}

Fig. 1. Dirichlet multinomial mixtures (DMM) clustering analyses of 16S rRNA data separate COVID-19 children into groups with distinctive features $(N=128)$. a. Eight distinct clusters were identified based on lowest Laplace approximation for control and patient samples from gut or nasal and throat cavities. Heat map showing the relative abundance of 40 most dominant bacterial genera per DMM cluster. The stars represent unclassified genera. H-GUT indicates abnormal gut microbial community structure of healthy children. H-MIX represents normal microbial community structure of a mixture of fecal, nasal and throat samples of healthy individuals. COVID-GUT I-III enriched in fecal samples of COVID-19 children; COVID-TN I-III enriched in both nasal and throat samples of COVID-19 children. b. Nonmetric multidimensional scaling (NMDS) visualization of DMM clusters using Bray-Curtis distance of bacterial genera. Significant separation of microbial community structures was implicated by the ANOSIM statistic R closer to 1 with $<0.05 \mathrm{P}$ value. The stress value lower than 0.2 provides a good representation in reduced dimensions. c. Box plots showing the alpha diversity (richness and evenness) per each DMM cluster. Wilcoxon test was used to compare difference of H-MIX cluster and others under three significance levels of $* \mathrm{P}<0.05, * * \mathrm{P}<0.01$, and $* * * \mathrm{P}<0.001$.

\section{Fig. 2. Identification (a) and relative abundance distribution (b) of indicator genera of eight}

DMM clusters. Indicators of eight microbial community types (DMM clusters) were identified from top 40 genus contributing to DMM clustering in Fig.1a (See Supplementary Methods). Twenty-one indicator genera are shared by two or more community types with similar diversity levels (e.g. II-III, or I-H-MIX). Significance levels of indicators are as follows: * $\mathrm{P}<0.05$, ** $\mathrm{P}<0.01$, and $* * * \mathrm{P}<$ 
medRxiv preprint doi: https://doi.org/10.1101/2020.07.13.20152181; this version posted July 17,2020 . The copyright holder for this preprint (which was not certified by peer review) is the author/funder, who has granted medRxiv a license to display the preprint in perpetuity. It is made available under a CC-BY-NC-ND 4.0 International license .

0.001 .

Fig. 3. Dynamic change of both DMM clusters (a) and six key taxa (b) in three body sites of

COVID-19 children. Age (months) of each COVID-19 child was shown in brackets. The community type levels were divergent between respiratory tract and gut (e.g. on days 11, 15 and 23 in CV04, and days 16 and 42 in CV09). The respiratory microbiome appeared to be progressively worsening in seven children (CV01-CV04 and CV07-CV09) for 25-42 days after symptom onset. The worsening of the gut microbiome appeared in four children (CV03, CV04, CV07 and CV09), and sustained for 25-52 days. b, key taxa of DMM clusters were shown in eight COVID-19 children with at least two time points of sampling. Linked to Supplementary Fig.2.

Fig. 4. Co-occurrence network of gut, nasal and throat microbiotas in the progression of higher than 0.4 and FDR-adjusted $\mathrm{P}$ values lower than 0.001 were shown. 
medRxiv preprint doi: https://doi.org/10.1101/2020.07.13.20152181; this version posted July 17, 2020. The copyright holder for this preprint (which was not certified by peer review) is the author/funder, who has granted medRxiv a license to display the preprint in perpetuity.

It is made available under a CC-BY-NC-ND 4.0 International license .

\section{Method}

\section{Study population}

Nine children were diagnosed as COVID-19 patients by Children's Hospital of Fudan University according to the National Guidelines for Diagnosis and Treatment of COVID-19. A total of 103 samples, including 31 nasal swabs, 28 throat swabs and 44 feces, were collected from these patients (Supplementary Fig. S1). Twenty-five samples from 14 age-matched healthy children were used as controls. The respiratory samples were collected using flexible, sterile, dry swabs, which can reach the posterior nasopharynx and oropharynx easily (approximately 2 inches). About $2 \mathrm{ml}$ spontaneous, unstimulated fecal specimen (300 mg/tube) was collected into a sterile cryogenic vial (Corning, NY, USA), divided into aliquots and stored at $-80{ }^{\circ} \mathrm{C}$ until use. The sampling was performed by the professionals at the hospital.

The study was approved by Children's Hospital of Fudan University (2020-27). Informed consents were obtained from involved patients or their guardians.

\section{Confirmation of COVID-19 children}

The clinical and epidemiological characteristics, and SARS-CoV-2 RNA shedding patterns of these patients were previously reported ${ }^{31,32}$. All nine COVID-19 children had mild symptoms. The virus RNA was extracted from all samples using a Mag-Bind RNA Extraction Kit (MACCURA, Sichuan, China) according to the manufacturer's instructions. The ORFlab and $N$ genes of SARS-CoV-2 was detected using a Novel Coronavirus (2019-nCoV) RNA detection Kit (PCR-Fluorescence Probing) (DAAN gene, Guangzhou, China) according to the manufacturer's instructions. 
medRxiv preprint doi: https://doi.org/10.1101/2020.07.13.20152181; this version posted July 17, 2020. The copyright holder for this preprint (which was not certified by peer review) is the author/funder, who has granted medRxiv a license to display the preprint in perpetuity.

It is made available under a CC-BY-NC-ND 4.0 International license .

\section{S rRNA gene sequencing}

All samples including nasal swabs, throat swabs and stool samples were subjected to the DNA extraction using a QIAamp DNA Microbiome Kit (QIAGEN, Düsseldorf, Germany). A novel tripleindex amplicon sequencing strategy was used for $16 \mathrm{~S}$ rRNA gene sequencing ${ }^{33}$. In brief, a set of universal bacterial primers was used to amplify the V4 hypervariable region (515-806 nt) of the $16 \mathrm{~S}$ rRNA gene. Two rounds of PCR amplifications were performed ${ }^{34}$. A reaction mixture containing 8 $\mu \mathrm{L}$ Nuclease-free water, $0.5 \mu \mathrm{L}$ KOD-Plus-Neo (TOYOBO, Osaka Boseki, Japan), $2.5 \mu \mathrm{L}$ of $1 \mu \mathrm{M}$ PCR1 forward primer, $2.5 \mu \mathrm{L}$ of $1 \mu \mathrm{M}$ PCR 1 reverse primer, and $5 \mu \mathrm{L}$ DNA template was prepared for the first round of the PCR (PCR1) amplification. PCR1 products were purified using Monarch DNA Gel Extraction Kit (New England Biolabs, Ipswich, MA, USA), and quantified by a Qubit® 4.0 Fluorometer (Invitrogen, Carlsbad, CA, USA). Purified PCR1 products were pooled with equal amounts, and then subjected to the secondary round of PCR (PCR2) amplification. The PCR2 mix contains $21 \mu \mathrm{L}$ Nuclease-free water, $1 \mu \mathrm{L}$ KOD-Plus-Neo (TOYOBO, Osaka Boseki, Japan), $5 \mu \mathrm{L}$ of $1 \mu \mathrm{M}$ PCR2 forward primer, $5 \mu \mathrm{L}$ of $1 \mu \mathrm{M}$ PCR 2 reverse primer, and $5 \mu \mathrm{L}$ pooled PCR1 products. The PCR2 products were purified using the same Gel Extraction Kit and qualified using the Qubit ${ }^{\circledR}$ 4.0 Fluorometer. The specific products were further qualified using Agilent 2100 Bioanalyzer (Agilent, Santa Clara, CA, USA). The PCR2 products with equal moles of specific products were pooled and mixed them with AMPure XP beads (Beckman Coulter, Pasadena, CA, USA) in a ratio of 0.8:1. After purification, the amplicons were paired-end sequenced $(2 \times 250)$ using Illumina-P250 sequencer.

\section{Bioinformatic analysis of $16 \mathrm{~S}$ rRNA gene sequence data}


medRxiv preprint doi: https://doi.org/10.1101/2020.07.13.20152181; this version posted July 17, 2020. The copyright holder for this preprint (which was not certified by peer review) is the author/funder, who has granted medRxiv a license to display the preprint in perpetuity.

It is made available under a CC-BY-NC-ND 4.0 International license.

Using USEARCH11 software ${ }^{35}$ and FASTX-Toolkit ${ }^{36}$, sequenced reads were merged, de-multiplexed and filtered. After trimming barcode, adapter and primer sequences using USEARCH11, 14,702, 896 sequences were retained with an average of 100019 sequences per sample. Based on the Qiime2 platform $^{37}$, the Deblur ${ }^{38}$ was used to cluster sequence data into sub-OTUs (operational taxonomic units), better than traditional OTU picking usually according to 97\% sequence similarity threshold which may miss subtle and real biological sequence variation ${ }^{39}$. In particular, we used the Deblur to perform quality control, dereplicate, chimeras remove on with default settings except for truncating sequence length to 250bp. A sub-OTU (sOTU) count table, equivalent to OTU table, was generated (2187 sOTUs). The taxonomic classification of sOTU representative sequences was assigned by using the RDP Naive Bayesian Classifier algorithm ${ }^{40}$ based on the Ribosomal Database project (RDP) $16 \mathrm{~S}$ rRNA training set (v16) database ${ }^{41}$. Finally, the sOTU table were subsampled at an even depth of 3600 sequences per sample to eliminate the bias led by different sequencing depths among samples. The sOTU coverage of $87 \%$ was sufficient to capture microbial diversity.

\section{Identification and characteristics of microbial community types}

Based on the bacterial genus abundance, we used the Dirichlet multinomial mixtures (DMM) ${ }^{42}$ algorithm introduced by mothur ${ }^{43}$ v1.44.1 to identify microbial community types because the DMM algorithm could efficiently cluster samples based on microbial composition, whose sensitivity, reliability and accuracy were widely confirmed in many microbiome studies ${ }^{16,44,45}$. Based on the lowest Laplace approximation index, the appropriate microbial community type numbers (DMM clusters) were determined. Conjugated with the Analysis of Similarities (ANOSIM), the reliability of DMM clustering was further validated and then visualized by the Non-metric multidimensional 
medRxiv preprint doi: https://doi.org/10.1101/2020.07.13.20152181; this version posted July 17, 2020. The copyright holder for this preprint (which was not certified by peer review) is the author/funder, who has granted medRxiv a license to display the preprint in perpetuity.

It is made available under a CC-BY-NC-ND 4.0 International license .

scaling (NMDS) based on the Bray-Curtis distance under bacterial genus level. "The ANOSIM statistic " $\mathrm{R}$ " compares the mean of ranked dissimilarities between groups to the mean of ranked dissimilarities within groups. An R value close to " 1.0 " suggests dissimilarity between groups while an $\mathrm{R}$ value close to "0" suggests an even distribution of high and low ranks within and between groups $^{\mathbf{4 6}}$. ANOSIM $\mathrm{p}$ values lower than 0.05 suggest the higher similarity within sites. Richness (Observed sOTUs) and Pielou's or Species evenness for each community type were calculated for estimating the difference of alpha diversity. Those analyses described above were performed using $\mathrm{R}$ package "vegan” v2.5-6. Using R package 'Pheatmap', the dynamic change of microbial community types and compositions were visualized. Alpha diversity difference between groups were measured using the Wilcoxon Rank Sum Test in R.

\section{Identification of indicator taxa contributing to microbial community typing}

To get the reliable indicator genus for community typing, we performed the Indicator Species Analysis using the indicspecies package (ver.1.7.8) ${ }^{47}$ in $\mathrm{R}$ platform with top 40 genus contributing to DMM clustering that accounted for $71 \%$ cumulative difference. Dynamic changes of indicator genera corresponding to each community type were showed in all COVID-19 children using the pheatmap package in $\mathrm{R}$.

\section{Co-occurrence network analysis of microbiomes among gut, nasal, and throat of COVID-19}

\section{children}

Based on microbial genus abundances of gut, nasal, and throat samples collected from 8 COVID-19 children, we calculated the Pearson Correlation Coefficient (Pearson's r) among bacterial genera of 
medRxiv preprint doi: https://doi.org/10.1101/2020.07.13.20152181; this version posted July 17, 2020. The copyright holder for this preprint (which was not certified by peer review) is the author/funder, who has granted medRxiv a license to display the preprint in perpetuity.

It is made available under a CC-BY-NC-ND 4.0 International license .

400

401

402

403

404

405

406

407

408

409

410

411

412

413

414

415

416

417

418

419

420

421

422

423

424

425

426

427

428

429

430

431

432

433

$434 \quad 44$

435

436

three body sites. The Pearson's $r$ higher than 0.4 or lower than -0.4 with $P$ values that were below

0.05 after the FDR adjustment were considered significant correlation. Co-occurrence network of significantly correlated bacterial genus pairs was visualized using Cytoscape v3.8.0 $0^{48}$.

\section{Data availability}

The raw data of 16S rRNA gene sequences are available at NCBI Sequence Read Archive (SRA)

(https://www.ncbi.nlm.nih.gov/sra/) at BioProject ID PRJNA642019.

31 Cai, J. et al. A Case Series of children with 2019 novel coronavirus infection: clinical and epidemiological features. Clin Infect Dis, ciaa198 (2020).

32 Liu, P. et al. Dynamic surveillance of SARS-CoV-2 shedding and neutralizing antibody in children with COVID-19. Emerg Microbes Infect 9, 1254-1258 (2020).

33 D'Amore, R. et al. A comprehensive benchmarking study of protocols and sequencing platforms for $16 \mathrm{~S}$ rRNA community profiling. Bmc Genomics 17, 55 (2016).

34 de Muinck, E. J., Trosvik, P., Gilfillan, G. D., Hov, J. R. \& Sundaram, A. Y. M. A novel ultra high-throughput 16S rRNA gene amplicon sequencing library preparation method for the Illumina HiSeq platform. Microbiome 5, 68 (2017).

35 Edgar, R. C. UPARSE: highly accurate OTU sequences from microbial amplicon reads. Nature Methods 10, 996-998 (2013).

36 Hannon, G. J. FASTX-Toolkit. http://hannonlab.cshl.edu/fastx_toolkit (2010).

37 Caporaso, J. G. et al. QIIME allows analysis of high-throughput community sequencing data. Nature Methods 7, 335-336 (2010).

38 Amir, A. Deblur rapidly resolves single-nucleotide community sequence patterns. mSystems. 2 (2017).

39 Knight, R. et al. Best practices for analysing microbiomes. Nature Reviews Microbiology 16, 410-422 (2018).

40 Wang, Q., Garrity, G. M., Tiedje, J. M. \& Cole, J. R. Naïve Bayesian Classifier for Rapid Assignment of rRNA Sequences into the New Bacterial Taxonomy. Applied and Environmental Microbiology 73, 5261 (2007).

41 Cole, J. R. et al. Ribosomal Database Project: data and tools for high throughput rRNA analysis. Nucleic Acids Research 42, D633-D642 (2013).

42 Holmes, I., Harris, K. \& Quince, C. Dirichlet Multinomial Mixtures: Generative Models for Microbial Metagenomics. PLOS ONE 7, e30126 (2012).

43 Schloss, P. D. et al. Introducing mothur: open-source, platform-independent, community-supported software for describing and comparing microbial communities. App/ Environ Microbio/ 75, 7537-7541 (2009).

44 Ding, T. \& Schloss, P. D. Dynamics and associations of microbial community types across the human body. Nature 509, 357-360 (2014).

45 Fujimura, K. E. et al. Neonatal gut microbiota associates with childhood multisensitized atopy and T cell 
medRxiv preprint doi: https://doi.org/10.1101/2020.07.13.20152181; this version posted July 17, 2020. The copyright holder for this preprint (which was not certified by peer review) is the author/funder, who has granted medRxiv a license to display the preprint in perpetuity. It is made available under a CC-BY-NC-ND 4.0 International license .

47

48

differentiation. Nature Medicine 22, 1187-1191 (2016).

Clarke, K. R. Non-parametric multivariate analyses of changes in community structure. Australian Journal of Ecology 18, 117-143 (1993).

47 De Cáceres, M., Legendre, P. \& Moretti, M. Improving indicator species analysis by combining groups of sites. Oikos 119, 1674-1684 (2010).

48 Otasek, D., Morris, J. H., Boucas, J., Pico, A. R. \& Demchak, B. Cytoscape Automation: empowering workflow-based network analysis. Genome Biol 20, 185 (2019).

Author contributions C.Z. conceived the study idea. C.Z., Z.Z. and J.X designed and supervised the study. P.L., M.Z. and J.X collected clinical samples and data. R.X., P.L. and Y.M. performed the experiments. T.Z. and Q.W. processed and analyzed the raw sequencing data. R.X., P.L., J.X. and M.Z. analyzed the clinical data. C.Z., Z.Z. and X.J. interpreted the data. Z.Z. and R.X. generated the figures. C.Z., Z.Z., R.X., and T.Z. wrote the first draft of the manuscript. X.J. contributed to critical revision. All authors contributed to the final manuscript.

Acknowledgements We thank Mr. Kai Liu and Mrs. Xiuming Wu at Institut Pasteur of Shanghai, Chinese Academy of Sciences for their technical support. This work was supported by the grants from the National Key Research and Development Program of China (2017ZX10103009-002 and 2018YFC2000500), the Second Tibetan Plateau Scientific Expedition and Research (STEP) program (2019QZKK0503), the Key Research Program of the Chinese Academy of Sciences (FZDSW-219), the Chinese National Natural Science Foundation (31970571) and grants specific for Coronavirus Disease 2019 from the Children's Hospital of Fudan University (Grant No. EKXGZX006).

Competing interests The authors declare no competing interests.

\section{Additional information}


medRxiv preprint doi: https://doi.org/10.1101/2020.07.13.20152181; this version posted July 17, 2020. The copyright holder for this preprint (which was not certified by peer review) is the author/funder, who has granted medRxiv a license to display the preprint in perpetuity.

It is made available under a CC-BY-NC-ND 4.0 International license .

Supplementary Table S1. Fecal, nasal, and throat microbial abundances (phyla and genera). The stars represent unclassified genera.

Supplementary Fig. S1. COIVD-19 patient admission and discharge times as well as the detection of SARS-CoV-2. DAY 1 was the day of symptom onset.

Supplementary Fig. S2. Dynamic change of 26 indicator genera in three body sites of nine COVID-19 children. Linked to Fig.2a and Fig.3b. The stars represent unclassified genera.

\section{Supplementary Fig. S3. Distinct gut and respiratory microbiome mechanisms associated with}

the progress of COVID-19 in adults and children. The dynamic mechanism of the microbiome in adults was interpreted from our recent observation based on the longitudinal throat and anal swabs from 35 adults with COVID-19 (Xu et al. unpublished data). Similar community types from I to III/IV indicate a progressive dysbiosis of the microbiome. In mild adults with COVID-19, a synchronous shift of community type from early dysbiosis towards late incomplete restoration was found in both respiratory and gut microbiomes within a short time. In children, however, the changes of the community types were divergent between the respiratory tract and gut, possibly implying that the "airway-gut axis" is still not established during the childhood. Moreover, children's respiratory microbiome appeared to be progressively worsening for a long period despite a fast clinical recovery. 
Fig.1

a

Controls

COVID-GUT

COVID-TN

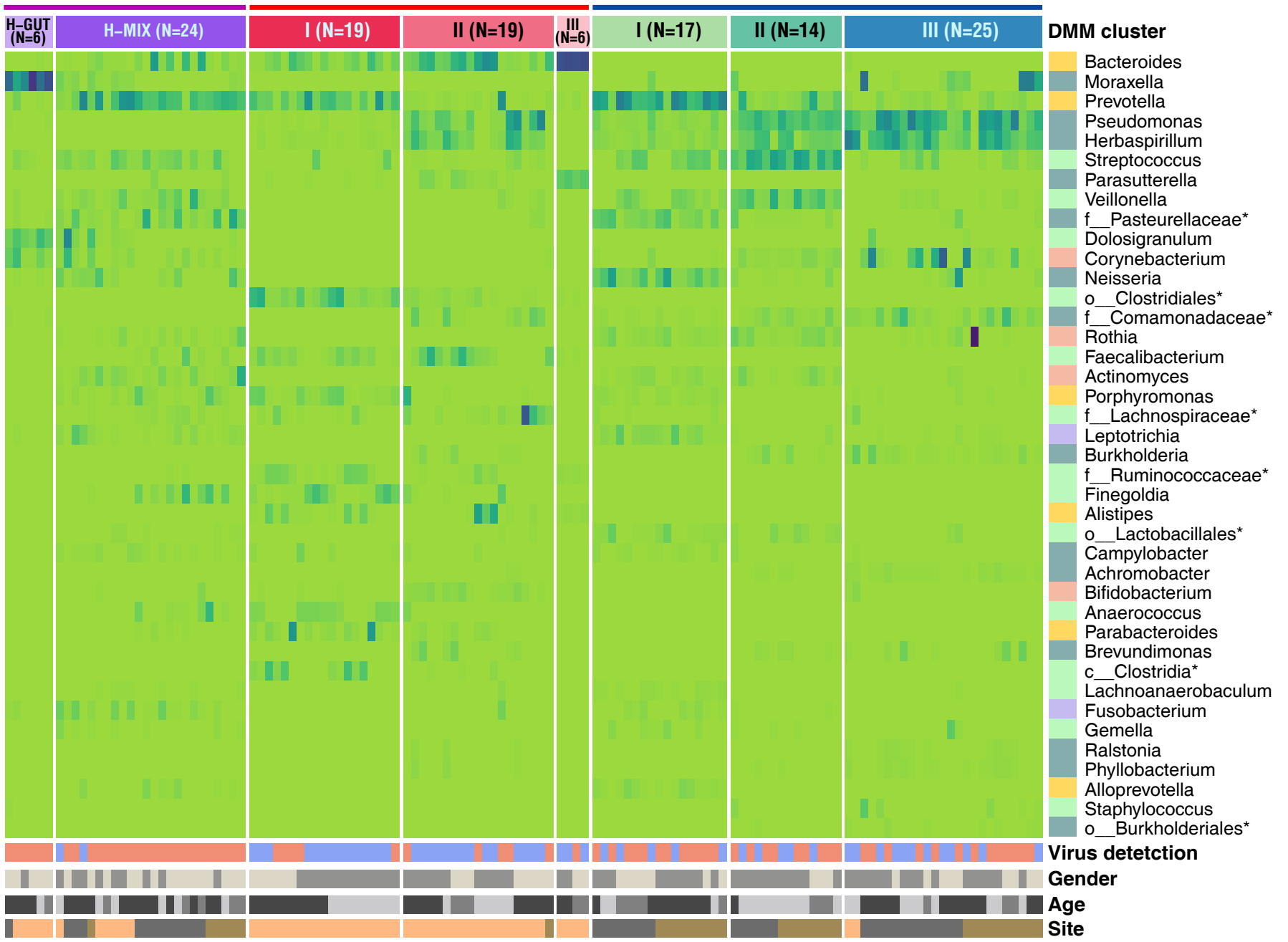

Bacterial Phyla

Actinobacteria

Bacteroidetes

Firmicutes

Fusobacteria

Proteobacteria

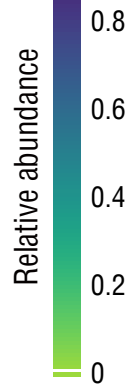

Virus detetction

negative

positive

Gender

Female

Male

Ages (years)

7 12

$4 \sim 5$

$<2$

Site

Gut

Nasal

Throat

b

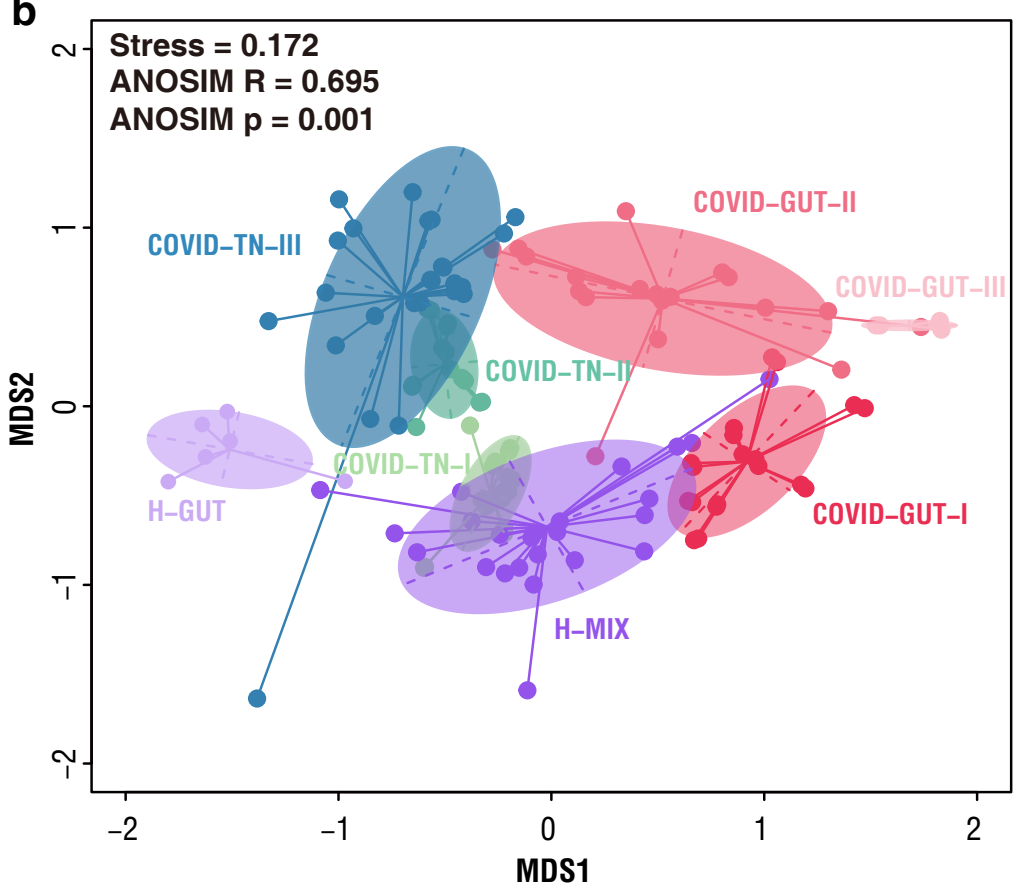

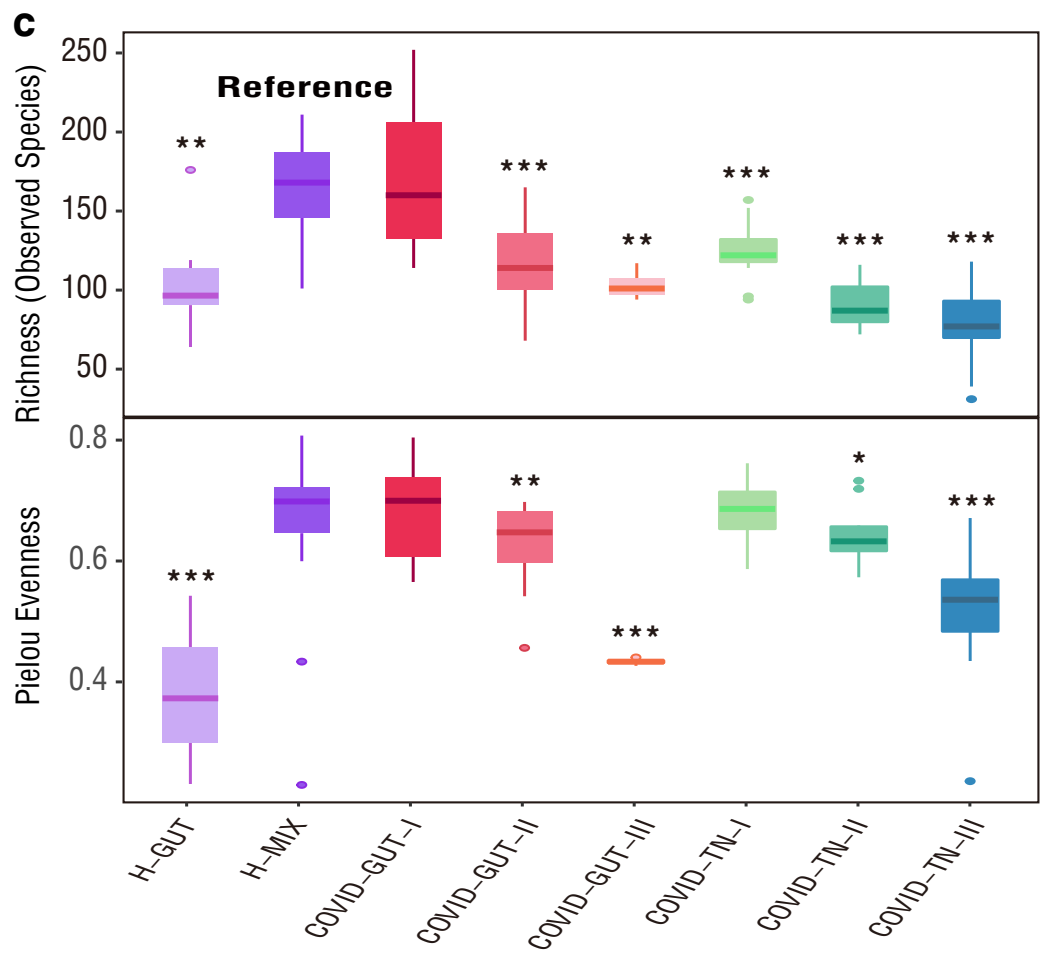


Fig. 2

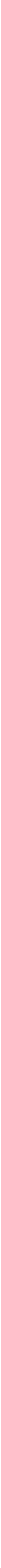

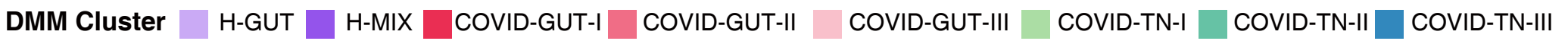

\begin{tabular}{|c|c|}
\hline Bacterial Phyla & Actinobacteria \\
\hline
\end{tabular}


Fig. 3

a

cvo9

(139 months)

6.

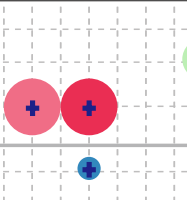

$\circ 8$

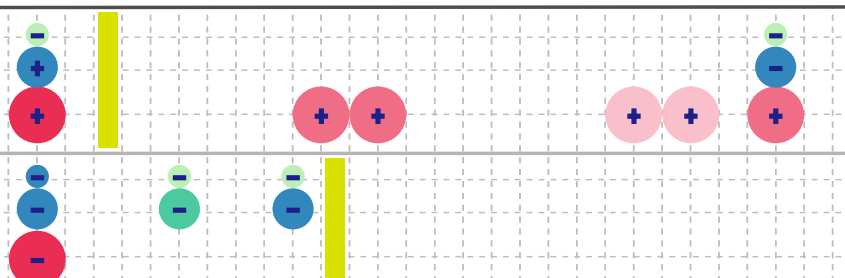

(13)

CV07

(127 months)

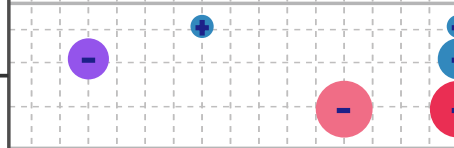

$8: 0$

CV06

(111 months)

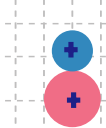

:
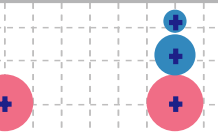

.

$+$

CV05

s)

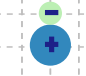

$+1$

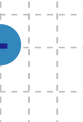

$-$

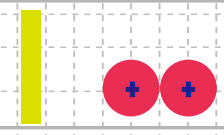

$+$

CV04

$+$

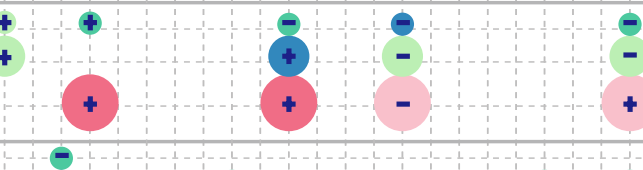

CV03

)

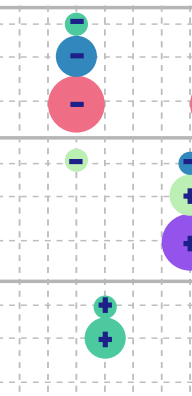

CVO1

CV02

(7 months)

-

Days after symptom onset

b
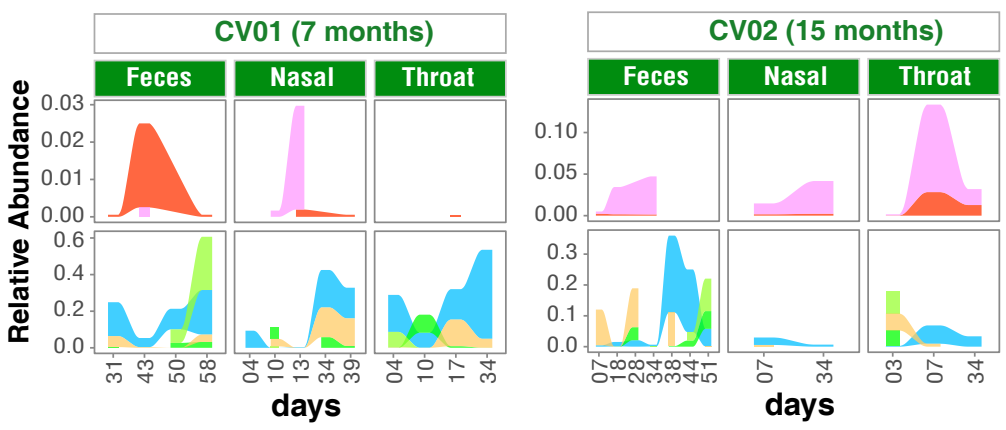

days

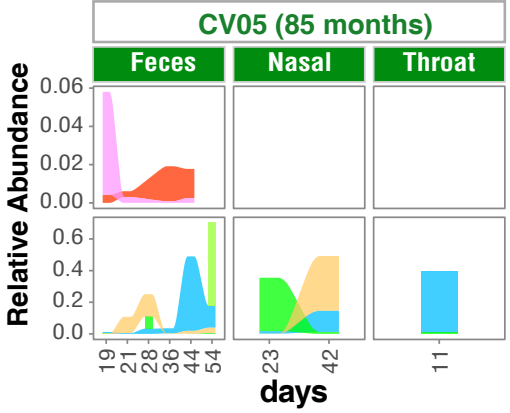

Key taxa

(Dominant Species)
Bifidobacterium

(B. longum)

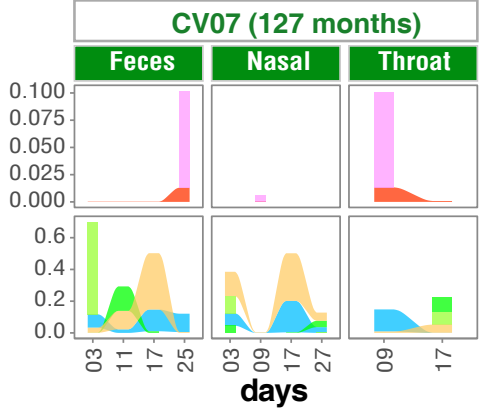

days

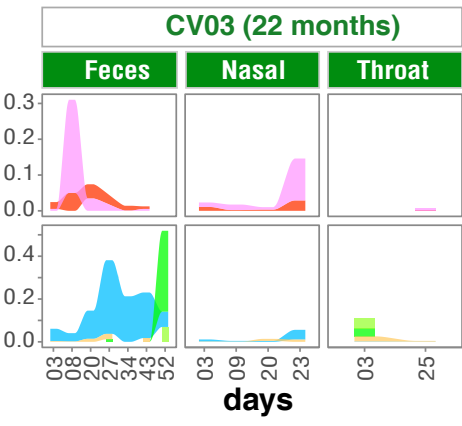

CV08 (132 months)

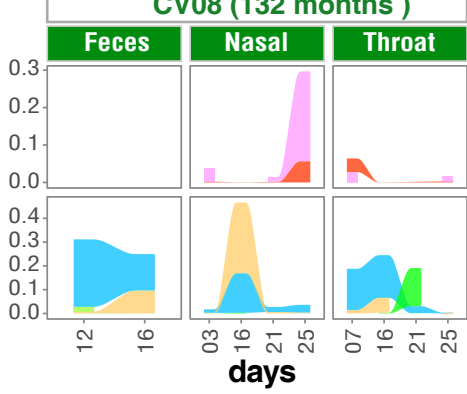

days

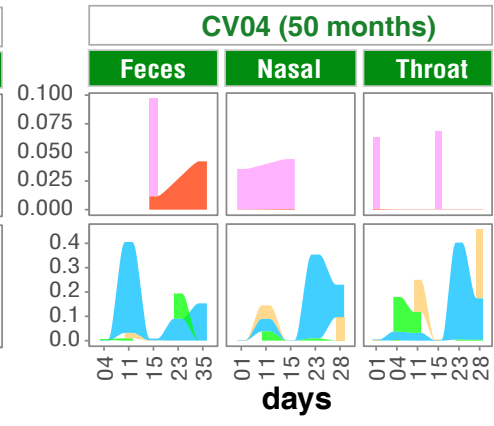

CV09 (139 months)

Feces Nasal Throat

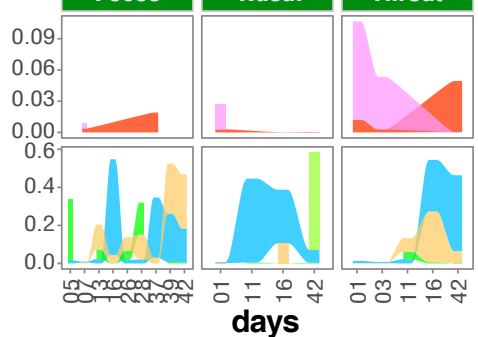

days
DMM Cluster

H-GUT

H-MIX

COVID-GUT-I

COVID-GUT-II

COVID-GUT-III

COVID-TN-I
COVID-TN-II
COVID-TN-III

Sites

Faeces

- Nasopharynx

- Throat

Virus Detection

- SARS-CoV-2 (Positive)

- SARS-CoV-2 (Negative)

Discharge time 


\section{Fig.4}
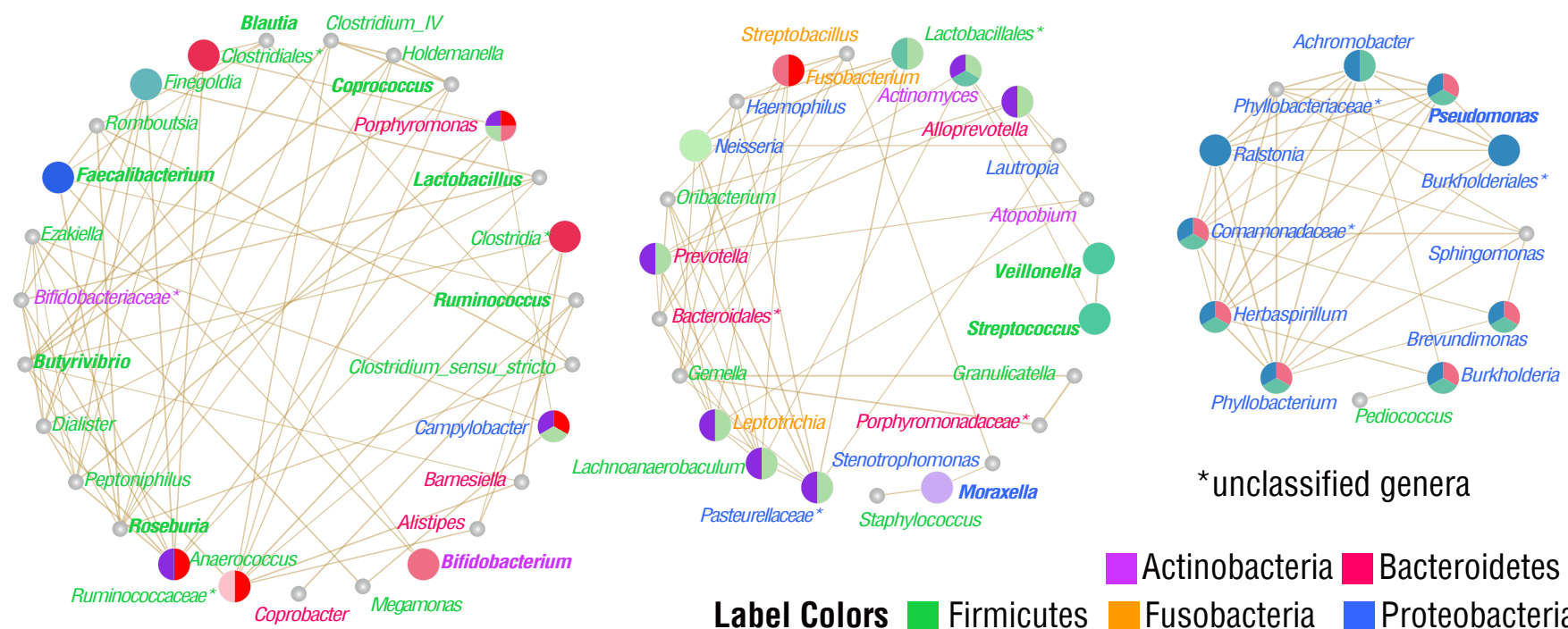

*unclassified genera

\section{Actinobacteria Bacteroidetes}

Label Colors Firmicutes Fusobacteria Proteobacteria

Indicator

Colors

H-GUTOH-MIX $\bigcirc$ COVID-GUT-I $\bigcirc$ COVID-GUT-II COVID-GUT-III $\bigcirc$ COVID-TN-I COVID-TN-II $\bigcirc$ COVID-TN-III 